\title{
Validation of SSR Markers for Foliar Disease Resistance in Groundnut (Arachis hypogaea L.)
}

\author{
R. Divyadharsini, R. Prabhu*, N. Manivannan and P. Vindhiyavarman \\ Department of Oilseeds, Centre for Plant Breeding and Genetics, \\ Tamil Nadu Agricultural University, Coimbatore - 641 003, Tamil Nadu, India \\ *Corresponding author
}

\begin{abstract}
A B S T R A C T
Groundnut (Arachis hypogaea L.) is an important food and cash crop with multifarious usages for resource poor farmers in Asia and Africa. Groundnut yield is constrained mainly due to two major foliar fungal diseases namely, late leaf spot and rust. The regular

\begin{tabular}{|c|}
\hline Keywords \\
\hline $\begin{array}{l}\text { Groundnut, } \\
\text { SSR markers, } \\
\text { SMA, Yield, } \\
\text { Late leaf spot, } \\
\text { Rust. }\end{array}$ \\
\hline Article Info \\
\hline $\begin{array}{l}\text { Accepted: } \\
\text { 12 March } 2017 \\
\text { Available Online: } \\
10 \text { April } 2017\end{array}$ \\
\hline
\end{tabular}
incidence of these diseases warrants the development of resistant cultivars and the recent advances in the area of crop genomics offer tools to assist breeding in groundnut. The present investigation was carried out to validate SSR markers in groundnut for disease resistance, which would further fasten the development of foliar disease resistant lines in groundnut. Crosses were made between foliar disease susceptible, CO 7 (female parent) and a disease resistant genotype, COG 0437 (male parent) and the resultants were further backcrossed to evolve $\mathrm{BC}_{3} \mathrm{~F}_{1}$ population in groundnut. Five markers viz., GM2301, IPAHM103, PM35, seq5D05 and seq8D09 were used for the validation in $\mathrm{BC}_{3} \mathrm{~F}_{1}$ population of $\mathrm{CO} 7 \times \mathrm{COG}$ 0437. Among the markers, the marker seq8D09 alone associated with late leaf spot and rust resistance. These markers accounted for 26.2 and $19.0 \%$ of phenotypic variation for late leaf spot and rust disease scores respectively. Single marker analysis was also carried out with these markers, genotypes and yield components. The marker GM2301 for number of pods plant ${ }^{-1}$; IPAHM103 for sound mature kernel (\%) and marker seq5D05 for 100-pod weight (g), 100-kernel weight (g) and shelling (\%) showed association in single marker analysis.
\end{abstract}

\section{Introduction}

Groundnut (Arachis hypogaea L.) is an important grain legume that serves as food and cash crop for resource poor farmers in Asia and Africa. It is a self pollinated, allotetraploid crop, with basic chromosome number ten $(2 \mathrm{n}=4 \mathrm{x}=40) \quad$ (Stebbins, 1957 ; Stalker and Dalmacio, 1986) and genome size $2800 \mathrm{Mb} / 1 \mathrm{C}$ (Guo et al., 2009). The native of groundnut is Brazil from where it was introduced into South Eastern Asia, Africa and USA in the $18^{\text {th }}$ century.
Groundnut is nutritious because its seeds typically contain high amounts of oil (45-55 $\%)$, protein $(25-30 \%)$ and other phytochemicals such as folic acid, tocopherol and antioxidants. In addition to protein and oil, groundnuts are a good source of minerals viz., copper, manganese, potassium, calcium, iron, magnesium, zinc and selenium. Apart from its nutritional value, groundnut has considerable medicinal value, and it is consumed in many ways and various forms. 
Although groundnut is an important multipurpose crop for resource poor farmers in the semi-arid tropics, due to environmental stresses and disease pressure, average productivity is often below expectation. Among many constraints, foliar diseases namely late leaf spot (LLS) caused by Phaeoisariopsis personata and rust caused by Puccinia arachidis are widespread and economically more important. These diseases often occur together and cause yield loss up to $70 \%$ in the crop (Subrahmanyam et al., 1985). These diseases also affect seed grade adversely and they markedly reduce haulm yield. Thus, breeding resistant cultivars is one of the best means of reducing crop yield losses from late leaf spot and also the best strategy to overcome additional cost of production (Prabhu et al., 2015). Selection of different genotypes under environmental stress conditions is one of the main tasks of plant breeders for exploiting genetic variations to improve disease tolerant cultivars (Clarke et al., 1984). Achieving a genetic improvement in yield under these environments has been recognized to be a difficult challenge for plant breeders while progress in kernel yields has been much higher in favourable environments (Richards et al., 2002).

Recent advances in the area of crop genomics offer tools to assist breeding (Varshney et al., 2006). Molecular markers and genetic linkage maps are pre-requisites for molecular breeding in any crop. It is used as a tool to identify major genes/QTL and thus it speeds up the process of introgression of beneficial traits into preferred varieties. Groundnut molecular breeding has been hindered by a shortage of polymorphic genetic markers due to a very narrow genetic base. Microsatellites (SSRs) are markers of choice in groundnut because they are co-dominant. Simple Sequence Repeats (SSR) can be used to separate cultivars (Moretzsohn et al., 2005) and this marker system holds great potential for developing useful markers to improve selection efficiency for traits in groundnut breeding. Novel efforts for the development of SSR genomic markers are important in order to increase the availability of this class of markers for genetic studies of the Arachis species. Many hundreds of SSR makers have been developed during recent years (Luo et $a l ., 2005)$, with less than 30 per cent being polymorphic among groundnut lines. Only few molecular markers identified have been linked with biotic resistance genes in groundnut. Hence, due to unavailability of tightly linked molecular markers, genetic improvement through marker is limited. However, many markers identified in preliminary genetic mapping studies are not suitable for direct use in marker-assisted selection. In order to overcome these limitations, molecular marker-trait association have been conducted and increasingly adopted in many plants (Butler et al., 2007). Hence, validation of SSR markers in groundnut for disease resistance would further fasten the development of foliar disease resistant lines in groundnut (Prabhu et al., 2016). In light of the above facts, the present investigation is contemplated with the objective to assess the marker-trait association through single marker analysis in $\mathrm{BC}_{3} \mathrm{~F}_{1}$ population of groundnut.

\section{Materials and Methods}

\section{Study area}

The present scientific investigation was carried out at Oilseeds Farm and Oilseeds Marker Assisted Selection Lab, Department of Oilseeds, Centre for Plant Breeding and Genetics, Tamil Nadu Agricultural University, Coimbatore.

\section{Experimental material}

Groundnut genotypes for the study consisted of a released variety $\mathrm{CO} 7$ (female parent) and 
an advanced breeding line COG 0437 (male parent) that are foliar disease susceptible and resistant to foliar fungal diseases respectively. Crosses were made between these two genotypes and resultants were further backcrossed to evolve $\mathrm{BC}_{3} \mathrm{~F}_{1}$ generation which was later used to validate SSR markers for foliar disease resistance in groundnut. The characteristic features of these genotypes are given in table 1 .

Phenotypic observations were recorded on nine characters viz., number of pods plant ${ }^{-1}$, 100-pod weight $(\mathrm{g}), 100$-kernel weight $(\mathrm{g})$, shelling (\%), sound mature kernel (\%), pod yield plant ${ }^{-1}(\mathrm{~g})$, kernel yield plant $^{-1}(\mathrm{~g})$, late leaf spot score and rust score.

\section{Molecular analysis}

Molecular marker analysis was carried out in $\mathrm{BC}_{3} \mathrm{~F}_{1}$ population of $\mathrm{CO} 7 \times \mathrm{COG} 0437$ cross using 16 SSR markers, linked to late leaf spot and rust resistance namely GM1009, GM1536， GM1573， GM2009， GM2079, GM2301, IPAHM103, PM3, PM35, PM50, PM137, seq5D05, seq8D09, seq13A07, seq13A10 and seq17F06 as reported by various authors (Table 2).

Genomic DNA was extracted by CTAB method (Doyle and Doyle, 1987) and the quality was checked by using $0.8 \%$ (w/v) agarose gel electrophoresis. All the 16 SSR markers linked to late leaf spot and rust resistance were used in this molecular analysis. The polymerase chain reaction (PCR) mixtures $(10 \mu \mathrm{l})$ contained $2 \mu \mathrm{l}$ template DNA (10 ng), $1 \mu \mathrm{l}$ of $10 \times$ Taq buffer $+\mathrm{MgCl}_{2}(15 \mathrm{mM}), 1 \mu \mathrm{l}$ of dNTP $(2 \mathrm{mM}), 0.5$ $\mu \mathrm{l}$ of primers $(10 \mu \mathrm{M}$ - Forward and Reverse), $0.1 \mu \mathrm{l}$ of $\mathrm{Taq}$ polymerase (Genei $3 \mathrm{IU} / \mu \mathrm{l})$ and $4.9 \mu \mathrm{l}$ of sterile double distilled water. Amplification was performed in $0.2 \mathrm{ml}$ (each tube) thin walled PCR plates (96 wells/plate) in a thermal cycler (Applied Biosystems). The samples were initially incubated at $94.0{ }^{\circ} \mathrm{C}$ for $3 \mathrm{~min}$ and then subjected to 20 times of the following cycle: $94.0^{\circ} \mathrm{C}$ for $30 \mathrm{~s}\left(-0.5{ }^{\circ} \mathrm{C}\right.$ reduction per cycle), $63.0^{\circ} \mathrm{C}$ for $30 \mathrm{~s}$ and 72.0 ${ }^{\circ} \mathrm{C}$ for $1 \mathrm{~min}$. This was followed by another 20 cycles of $94.0^{\circ} \mathrm{C}$ for $15 \mathrm{~s}, 55.0^{\circ} \mathrm{C}$ for $30 \mathrm{~s}$ and $72.0^{\circ} \mathrm{C}$ for $1 \mathrm{~min}$. Final extension was $72.0{ }^{\circ} \mathrm{C}$ for $10 \mathrm{~min}$. Amplified products were analyzed using $6 \%$ non denaturing polyacrylamide gel at constant power 150 volts for about $4 \mathrm{~h}$ and silver stained (Benbouza et al., 2006).

\section{Data scoring}

Clear and unambiguous bands were scored as 1,2 and 3 for parent 1, heterozygote and parent 2 banding pattern respectively. The data matrix thus obtained was subjected to further analysis.

\section{Single marker analysis}

Single marker analysis was carried out in 72 individuals of $\mathrm{BC}_{3} \mathrm{~F}_{1}$ population of $\mathrm{CO} 7 \times$ COG 0437 in order to identify the association between the markers and the disease score as well as yield and its component traits. It is used to detect the potential association between marker classes and their respective phenotypic values (Edwards et al., 1987; Gupta, 2002). A simple linear regression approach was used in which the phenotypic trait served as the dependent variable and the marker as the independent variable. Regression analysis was done using the SPSS 16.0 software. The adjusted $\mathrm{R}^{2}$ value was used as \% of phenotypic variance explained by the marker on the particular trait of interest.

\section{Results and Discussion}

\section{Parental polymorphic studies}

In the present study, two parents $\mathrm{CO} 7$ and COG 0437 were taken for polymorphic studies using 16 SSR markers. 
Table.1 Characteristic features of parental materials used in present study

\begin{tabular}{|c|c|c|c|c|}
\hline Genotype & Pedigree & Habit & Foliar Diseases & Special Features \\
\hline $\mathrm{CO} 7$ & $\begin{array}{l}\text { Derivative from cross } \\
\text { ICGV } 87290 \times \text { ICGV } \\
87846\end{array}$ & Spanish bunch & Susceptible & $\begin{array}{l}\text { Superior for pod } \\
\text { yield, drought } \\
\text { tolerant }\end{array}$ \\
\hline COG 0437 & $\begin{array}{l}\text { Derivative from cross } \\
\text { CO } 2 \times \text { ICGV } 94118\end{array}$ & Virginia bunch & Resistant & $\begin{array}{l}\text { High yield potential } \\
\text { with } 50-51 \% \text { oil } \\
\text { content }\end{array}$ \\
\hline
\end{tabular}

Table.2 Information on SSR markers used for validation in groundnut

\begin{tabular}{|c|c|c|c|}
\hline S.No. & Marker & Forward (F) and Reverse (R) Sequence & Reference \\
\hline 1 & GM1009 & $\begin{array}{l}\text { F: TTTCCTTCTTTCCCTTCTTCTTC } \\
\text { R: CGTTGTTGCCGTTAAACTGA }\end{array}$ & Sujay et al., 2012 \\
\hline 2 & GM1536 & $\begin{array}{l}\text { F: AAAGCCCTGAAAAGAAAGCAG } \\
\text { R: CAACCAGCTCCTTCTCTACCC }\end{array}$ & $\begin{array}{l}\text { Sujay et al., 2012; } \\
\text { Sukruth et al., 2015 }\end{array}$ \\
\hline 3 & GM1573 & $\begin{array}{l}\text { F: GAGACCGGAGACGGAGAGTAT } \\
\text { R: ACGCCCATAGATTAACCCAGT }\end{array}$ & Sujay et al., 2012 \\
\hline 4 & GM2009 & $\begin{array}{l}\text { F: CAAACGCATACACCCCATAAC } \\
\text { R: TTTGGTTCTCGTTTGTGTTTT }\end{array}$ & $\begin{array}{l}\text { Sujay et al., 2012; } \\
\text { Sukruth } \text { et al., 2015 }\end{array}$ \\
\hline 5 & GM2079 & $\begin{array}{l}\text { F: GGCCAAGGAGAAGAAGAAAGA } \\
\text { R: GAAGGAGTAGTGGTGCTGCTG }\end{array}$ & $\begin{array}{l}\text { Sujay et al., 2012; } \\
\text { Sukruth } \text { et al., } 2015\end{array}$ \\
\hline 6 & GM2301 & $\begin{array}{l}\text { F: GTAACCACAGCTGGCATGAAC } \\
\text { R: TCTTCAAGAACCCACCAACAC }\end{array}$ & $\begin{array}{l}\text { Sujay et al., 2012; } \\
\text { Sukruth } \text { et al., } 2015\end{array}$ \\
\hline 7 & IPAHM103 & $\begin{array}{l}\text { F: GCATTCACCACCATAGTCCA } \\
\text { R: TCCTCTGACTTTCCTCCATCA }\end{array}$ & $\begin{array}{l}\text { Khedikar et al., 2010; } \\
\text { Sukruth } \text { et al., } 2015\end{array}$ \\
\hline 8 & PM3 & $\begin{array}{l}\text { F: GAAAGAAATTATACACTCCAATTATGC } \\
\text { R: CGGCATGACAGCTCTATGTT }\end{array}$ & $\begin{array}{l}\text { Shoba et al., 2012; } \\
\text { Shirasawa et al., } 2013\end{array}$ \\
\hline 9 & PM50 & $\begin{array}{l}\text { F: CAATTCATGATAGTATTTTATTGGACA } \\
\text { R: CTTTCTCCTCCCCAATTTGA }\end{array}$ & $\begin{array}{l}\text { Mondal and Badigannavar, } \\
2010\end{array}$ \\
\hline 10 & PM137 & $\begin{array}{l}\text { F: AACCAATTCAACAAACCCAGT } \\
\text { R: GAAGATGGATGAAAACGGATG }\end{array}$ & $\begin{array}{l}\text { Shoba et al., 2012; } \\
\text { Shirasawa et al., } 2013\end{array}$ \\
\hline 11 & PM35 & $\begin{array}{l}\text { F: TGTGAAACCAAATCACTTTCATTC } \\
\text { R: TGGTGAAAAGAAAGGGGAAA }\end{array}$ & $\begin{array}{l}\text { Mondal and Badigannavar, } \\
\text { 2010; Shirasawa et al., } 2013\end{array}$ \\
\hline 12 & seq5D05 & $\begin{array}{l}\text { F: AAAAGAAAGACCTTCCCCGA } \\
\text { R: GCAGGTAATCTGCCGTGATT }\end{array}$ & $\begin{array}{l}\text { Shoba et al., 2012; } \\
\text { Shirasawa et al., } 2013\end{array}$ \\
\hline 13 & seq8D09 & $\begin{array}{l}\text { F: TGAGTTTCCCCAAAAGGAGA } \\
\text { R: CAACAACAATACGGCCAACA }\end{array}$ & Sujay et al., 2012 \\
\hline 14 & seq13A07 & $\begin{array}{l}\text { F: AATCCGACGCAATGATAAAAA } \\
\text { R: TCCCCTTATTGTTCCAGCAG }\end{array}$ & $\begin{array}{l}\text { Varma et al., 2005; } \\
\text { Shirasawa et al., } 2013\end{array}$ \\
\hline 15 & seq13A10 & $\begin{array}{l}\text { F: AACTCGCTTGTACCGGCTAA } \\
\text { R: AGGAATAATAACAATACCAACAGCA }\end{array}$ & Mace et al., 2006 \\
\hline 16 & seq17F06 & $\begin{array}{l}\text { F: CGTCGGATTTATCTGCCAGT } \\
\text { R: AGTAGGGGCAAGGGTTGATG }\end{array}$ & $\begin{array}{l}\text { Mace et al., 2006; } \\
\text { Shirasawa } \text { et al., } 2013\end{array}$ \\
\hline
\end{tabular}


Table.3 Variability for different characters in $\mathrm{BC}_{3} \mathrm{~F}_{1}$ population of groundnut

\begin{tabular}{clcccc}
\hline S.No. & \multicolumn{1}{c}{ Character } & Mean & Minimum & Maximum & CV (\%) \\
\hline 1 & Number of pods plant $^{-1}$ & 13.74 & 2.00 & 31.00 & 43.75 \\
2 & 100-pod weight $(\mathrm{g})$ & 86.32 & 29.40 & 132.40 & 19.25 \\
3 & 100-kernel weight $(\mathrm{g})$ & 30.95 & 0.00 & 46.35 & 22.15 \\
4 & Shelling $(\%)$ & 61.61 & 11.65 & 79.44 & 21.03 \\
5 & Sound mature kernel $\left.(\%)^{-1}\right)$ & 93.01 & 0.00 & 100.00 & 16.36 \\
6 & Pod yield plant $^{-1}(\mathrm{~g})$ & 11.39 & 1.03 & 24.10 & 45.47 \\
7 & Kernel yield plant $^{-1}(\mathrm{~g})$ & 7.33 & 0.12 & 16.73 & 51.71 \\
8 & Late leaf spot score $_{9}$ & 4.58 & 3.00 & 6.00 & 14.06 \\
\hline
\end{tabular}

Table.4 Single marker analysis for various traits in $\mathrm{CO} 7 \times \mathrm{COG} 0437\left(\mathrm{BC}_{3} \mathrm{~F}_{1}\right)$ of groundnut

\begin{tabular}{clcc}
\hline S.No. & \multicolumn{1}{c}{ Character } & Marker & Adjusted R $^{\mathbf{2}}(\boldsymbol{\%})$ \\
\hline 1 & Number of pods plant & GM2301 & 6.1 \\
2 & 100-pod weight $(\mathrm{g})$ & seq5D05 & 5.0 \\
3 & 100-kernel weight $(\mathrm{g})$ & seq5D05 & 10.4 \\
4 & Shelling (\%) & seq5D05 & 8.2 \\
5 & Sound mature kernel (\%) & IPAHM103 & 6.8 \\
6 & Late leaf spot score & seq8D09 & 26.2 \\
7 & Rust score & seq8D09 & 19.0 \\
\hline
\end{tabular}

Plate.1 Genotypic profile using molecular marker in $\mathrm{BC}_{3} \mathrm{~F}_{1}$ generation of groundnut

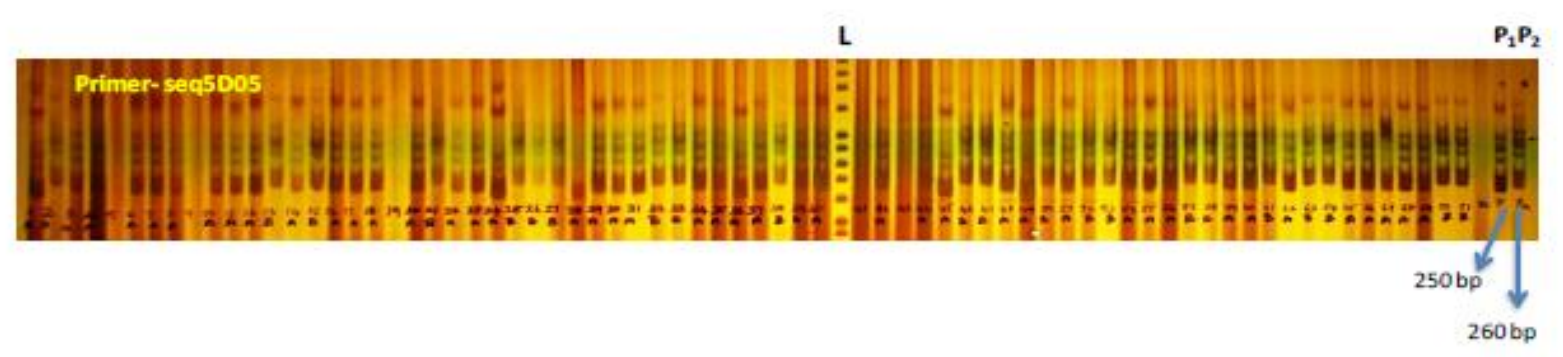

$$
\mathbf{L}-20 \text { bp ladder, } \mathbf{P}_{\mathbf{1}}-\mathrm{CO} 7, \mathbf{P}_{\mathbf{2}}-\mathrm{COG} 0437
$$

Among these markers, five (GM2301, IPAHM103, PM35, seq5D05 and seq8D09) were polymorphic between two parents and used further profiling of the $\mathrm{BC}_{3} \mathrm{~F}_{1}$ population. The genotypic profiling using molecular marker is shown in Plate 1.

\section{Single marker analysis}

Single marker analysis is the simplest method for detecting QTLs associated with single markers. The statistical methods used for single marker analysis include $t$-tests, analysis of variance (ANOVA) and linear regression. Linear regression is most commonly used because the coefficient of determination $\left(\mathrm{R}^{2}\right)$ from the marker explains the phenotypic variation explained by the QTL linked to the marker. The phenotypic and genotypic data of $\mathrm{BC}_{3} \mathrm{~F}_{1}$ population were subjected to single marker analysis (SMA) using single factor 
regression analysis using the marker (as independent) and the respective phenotype (as dependent) as suggested by Sax, 1923. The significant regression 'value b' indicated that the particular marker is linked to trait. The adjusted $\mathrm{R}^{2}$ value was considered as the $\%$ of phenotypic variability of the traits explained by the marker (PVE).

In this study, $72 \mathrm{BC}_{3} \mathrm{~F}_{1}$ individuals of $\mathrm{CO} 7 \times$ COG 0437 and five polymorphic SSR markers were subjected to single marker analysis (Tables 3 and 4). The PVE value varied from 5.0 to $26.2 \%$. Even though five markers were polymorphic between two parents, only one marker seq8D09 was associated with late leaf spot and rust resistance in groundnut with the PVE value of $26.2 \%$ and $19.0 \%$ respectively. Hence, the marker seq8D09 may be useful for foliar disease resistance programme in groundnut. With respect to other traits, the marker GM2301 is associated with number of pods plant $^{-1}$ with $6.1 \%$ of PVE. The marker IPAHM103 associated with sound mature kernel (\%) with PVE of $6.8 \%$. While, the marker seq5D05 associated with 100-pod weight $(\mathrm{g}), 100$-kernel weight $(\mathrm{g})$ and shelling (\%) with PVE of 5.0, 10.4 and $8.2 \%$ respectively. It indicated that the genes associated with resistance to late leaf spot and rust may also be controlling the expression of these characters.

In conclusion, considering the molecular analysis in $\mathrm{CO} 7 \times \mathrm{COG} 0437\left(\mathrm{BC}_{3} \mathrm{~F}_{1}\right)$ of groundnut, five markers viz., GM2301, IPAHM103, PM35, seq5D05 and seq8D09 were found to be polymorphic. The marker seq8D09 alone associated with late leaf spot and rust resistance which explains 26.2 and $19.0 \%$ of phenotypic variations respectively. Hence this marker may be useful for foliar disease resistance programme in groundnut. With respect to yield attributes, the marker GM2301 and IPAHM103 was associated with number of pods plant ${ }^{-1}$ and sound mature kernel (\%) while, the marker seq5D05 for 100-pod weight $(\mathrm{g})$, 100-kernel weight $(\mathrm{g})$ and shelling (\%) respectively. Hence these markers may be used in the marker assisted breeding to improve the respective traits.

\section{References}

Anitha, B.K. 2013. Identification of quantitative trait loci for oil yield and marker assisted backcross for high oleic acid in groundnut (Arachis hypogaea L.). Ph.D. (Ag.) Thesis. Submitted to the Tamil Nadu Agricultural University, Coimbatore.

Benbouza, H., Jacquemin, J.M., Baudoin, J.P. and Mergeai, G. 2006. Optimization of a reliable, fast, cheap and sensitive silver staining method to detect SSR markers in polyacrylamide gels. Biotechnol. Agron. Soc. Environ., 10(2): 77-81.

Butler, D.R., Wadia, K.D.R. and Jadhav, D.R. 2007. Effects of leaf wetness and temperature on late leaf spot infraction of groundnut. Plant Pathol., 43(1): 112120.

Clarke, J.M., Smith, T.M.T., McCaig, T.N. and Green, D.G. 1984. Growth analysis of spring wheat cultivars of varying drought resistance. Crop Sci., 24(3): 537-541.

Doyle, J.J. and Doyle, J.L. 1987. A rapid DNA isolation procedure for small quantities of fresh leaf tissue. Phytochem. Bull., 19: 11-15.

Edwards, M.D., Stuber, C.W. and Wendel, J.F. 1987. Molecular-marker-facilitated investigations of quantitative-trait loci in maize. Numbers, genomic distribution and types of gene action. Genetics, 116(1): 113-125.

Gautami, B., Fonce, D., Pandey, M.K., Moretzsohn, M.C., Sujay, V., Qin, H., Hong, Y., Faye, I., Chen, X., Prakash, A.B., Shah, T.M., Gowda, M.V.C., 
Nigam, S.N., Liang, X., Hoisington, D.A., Guo, B., Bertioli, D.J., Rami, J.F. and Varshney, R.K. 2012. An International reference consensus genetic map with 897 marker loci based on 11 mapping populations for tetraploid groundnut (Arachis hypogaea L.). PLoS One, 7(7): 1-11.

Guo, B., Chen, X., Hong, Y., Liang, X., Dang, P., Brenneman, T., Holbrook, C. and Culbreath, A. 2009. Analysis of gene expression profiles in leaf tissues of cultivated peanuts and development of EST-SSR markers and gene discovery. Int. J. Plant Genomics, 1-14.

Gupta, P. 2002. Molecular markers and QTL analysis in crop plants. Curr. Sci., 83(2): 113-114.

Khedikar, Y.P., Gowda, M.V.C., Sarvamangala, C., Patgar, K.V., Upadhyaya, H.D. and Varshney, R.K. 2010. A QTL study on late leaf spot and rust revealed one major QTL for molecular breeding for rust resistance in groundnut (Arachis hypogaea L.). Theoretical and Appl. Genetics, 121: 971-984.

Luo, M., Dang, P., Bausher, M.G. and Holbrook, C.C. 2005. Identification of transcripts involved in resistance responses to leaf spot disease caused by Cercosporidium personatum in peanut (Arachis hypogaea L.). Phytopathol., 95: 381-387.

Mace, E.S., Phong, D.T., Upadhaya, H.D., Chandra, S. and Crouch, J.H. 2006. SSR analysis of cultivated groundnut (Arachis hypogaea L.) germplasm resistant to rust and late leaf spot diseases. Euphytica, 152(3): 317-330.

Mondal, S. and Badigannavar, A.M. 2010. Molecular diversity and association of SSR markers to rust and late leaf spot resistance in cultivated groundnut (Arachis hypogaea L.). Plant Breeding, 129: 68-71.
Moretzsohn, M.C., Leoi, L., Proite, K., Guimaraes, P.M., Bertioli, S.C.M.L., Gimenes, M.A., Martins, W.S., Valls, J.F.M., Grattapaglia, D. and Bertioli, D.J. 2005. A microsatellite-based, generich linkage map for the AA genome Arachis. Theoretical and Appl. Genetics, 111(6): 1060-1071.

Prabhu, R., Manivannan, N., Mothilal, A. and Ibrahim, S.M. 2015. Estimates of genetic variability parameters for yield and yield attributes in groundnut (Arachis hypogaea L.). Int. J. Agri. Environ. Biotechnol., 8(3): 551-559.

Prabhu, R., Manivannan, N., Mothilal, A. and Ibrahim, S.M. 2016. Screening for parental polymorphism using molecular markers in groundnut (Arachis hypogaea L.). Adv. Life Sci., 5(12): 5347-5352.

Richards, R.A., Rebetzke, G.J., Condon, A.G. and Herwaarden, A.F.V. 2002. Breeding opportunities for increasing the efficiency of water use and crop yield in temperate cereals. Crop Sci., 42(1): 111-121.

Sax, K. 1923. The association of size differences with seed coat pattern and pigmentation in Phaseolus vulgaris. Genetics, 8: 552-560.

Shirasawa, K., Bertioli, D.J., Varshney, R.K., Moretzsohn, M.C., Leal-Bertioli, S.C.M., Thudi, M., Pandey, M.K., Rami, J.F., Fonceka, D., Gowda, M.V.C., Qin, H., Guo, B., Hong, Y., Liang, X., Hirakawa, H., Tabata, S. and Isobe, S. 2013. Integrated consensus map of cultivated peanut and wild relatives reveals structures of the A and B genomes of Arachis and divergence of the legume genomes. DNA Res., 20: 173-184.

Shoba, D., Manivannan, N., Vindhiyavarman, P. and Nigam, S.N. 2012. SSR markers associated for late leaf spot disease resistance by bulked segregant analysis 
in groundnut (Arachis hypogaea L.). Euphytica, 188(2): 265-272.

Smith, J.S.C., Chin, E.C.L., Shu, H., Smith, O.S., Wall, S.J., Senior, M.L., Mitchell, S.E., Kresovich, S. and Zeigle, J. 1997. An evaluation of the utility of SSR loci as molecular markers in maize (Zea mays L.): comparisons with data from RFLPs and pedigree. Theoretical Appl. Genetics, 95: 163-173.

Stalker, H.T. and Dalmacio, R.D. 1986. Karyotype analysis and relationships among varieties of Arachis hypogaea $\mathrm{L}$. Cytologia, 58: 617-629.

Stebbins, G.L. 1957. Genetics, Evolution and Plant breeding. Indian J. Genetics and Plant Breeding, 17: 129-141.

Subrahmanyam, P., Ghanekar, B.L., Nolt, B.L., Reddy, D.V.R. and McDonald, D. 1985. Resistance to groundnut diseases in wild Arachis species. In: Proceedings of an International workshop on cytogenetics of Arachis. ICRISAT Centre, Patancheru, India, 49-55.

Sujay, V., Gowda, M.V.C. and Pandey, M.K. 2012. Quantitative trait locus analysis and construction of consensus genetic map for foliar disease resistance based on two recombinant inbred line populations in cultivated groundnut (Arachis hypogaea L.). Mol. Breed., 30: 773-788.

Sukruth, M., Paratwagh, S.A., Sujay, V., Kumari, V., Gowda, M.V.C., Nadaf, H.L., Motagi, B.N., Lingaraju, S., Pandey, M.K., Varshney, R.K. and Bhat, R.S. 2015. Validation of markers linked to late leaf spot and rust resistance, and selection of superior genotypes among diverse recombinant inbred lines and backcross lines in peanut (Arachis hypogaea L.). Euphytica, 204: 343-351.

Varma, T.S.N., Dwivedi, S.L., Pande, S. and Gowda, M.V.C. 2005. SSR markers associated with resistance to rust (Puccinia arachidis Speg.) in groundnut (Arachis hypogaea L.). SABRO J., 37(2): 107-119.

Varshney, R.K., Hoisington, D.A. and Tyagi, A.K. 2006. Advances in cereal genomics and applications in crop breeding. Trends in Biotechnol., 24: 490-499.

\section{How to cite this article:}

Divyadharsini, R., R. Prabhu, N. Manivannan and Vindhiyavarman, P. 2017. Validation of SSR Markers for Foliar Disease Resistance in Groundnut (Arachis hypogaea L.). Int.J.Curr.Microbiol.App.Sci. 6(4): 1310-1317. doi: https://doi.org/10.20546/ijcmas.2017.604.160 